\title{
Handicap and Tinkering of a Sports Career: Case of Tunisia
}

\author{
Imen Ben Amar' ${ }^{1}$, Ali Elloumi², Abdessatar Sahbeni ${ }^{3}$ \\ ${ }^{1}$ ECUMUS Laboratory, University of Mannouba, Manouba, Tunisia \\ ${ }^{2}$ TEC Laboratory, University Paris Descartes, Paris, France \\ ${ }^{3}$ ECUMUS Laboratory, University of Tunis, Tunis, Tunisia \\ Email:Imen_benamar21@yahoo.fr, alielloumi62@gmail.com
}

How to cite this paper: Amar, I. B., Elloumi, A., \& Sahbeni, A. (2019). Handicap and Tinkering of a Sports Career: Case of Tunisia. Advances in Applied Sociology, 9, 288-305.

https://doi.org/10.4236/aasoci.2019.97022

Received: May 5, 2019

Accepted: July 9, 2019

Published: July 12, 2019

Copyright $\odot 2019$ by author(s) and Scientific Research Publishing Inc. This work is licensed under the Creative Commons Attribution International License (CC BY 4.0).

http://creativecommons.org/licenses/by/4.0/

\begin{abstract}
The purpose of this article is to show the interest of craft as a sociological paradigm in the development of a sporting career of a handicap Tunisian athlete. Meeting the demands of a sporting career, the athlete goes through different stages of representation of disability. The representation is made from stage such as (shaped, composed, performed) through his or her sporting career. We analyzed the life story of "W" and " $H$ ", two Tunisian Paralympic champions and their Sports career. This analysis allowed us to illustrate the necessity imposed by the social environment. It seems that athletes consider primarily the interactions in which it will keep the opportunity open and hazardous to their itinerary to finally pursue their individual actions. These actions are used to the structures, interactions, rational, irrational, subjectivity and objectivity. An entry in the sporting career which we have identified as an entry using the paradigm of high-level sports career craft formally determines the complexity of the professionalization of the Tunisian handicap. The interviews are guided by three dimensions related to civil status, sporting and social. The results indicate the sports career of a Tunisian handicap is filled with obstacle and obstructions. A difficult choice to keep that characterizes their existence and their sporting career. Passing through three stages of representation of disability: the "cursed" disability "used" disability and handicap "revered" the athlete who saw a fashioned route and anchored ambivalent and whose primary objective was the public recognition and social success. This success is achieved through learning a skill and a life of bricolage favoring the construction of a disability representation in sports career.
\end{abstract}

\section{Keywords}

Life Course, Career, Hobby, Determinism, Rationality, Disability 


\section{Introduction}

In Tunisia, the definition of disability and the number of people with disabilities are marginalized. Indeed, the UN called on the Tunisian government to review its definition of disability to better adapt to the agreements signed in this field. This confusion of definition considered among the first torments of Tunisian disability provides in most cases the percentages of disability waves. In fact, it appears that only $45 \%$ of disabled people hold a disability card (Poizat, 2009: p. 31). Tunisia also poses other problems for people with disabilities, such as visualization, lack of childcare facilities and public facilities suitable for disabled without forgetting the social and professional integration. It should be noted that the unemployment rate reached $40 \%$.

Besides the confusion of the definition and the lack of appropriate structures, the major problem of disability is also from the social culture including the mentality of the Arab-Muslim traditional society that has a stigma of disability. A stigma still persists in our Tunisian mentality. It's a kind of a negative assessment of the person. Among the stigma identified by Goffman (1975: p. 17), the abominations of the body i.e. the physical stigmata, it is the physical disorders and defects of the face or body. The attitude of the normal face stigmatized causes discrimination practices. The result of this discrimination, a feeling of shame and contempt among the stigmatized especially in the absence of the reference group in which he could fit.

\section{The Disabilities in Tunisia Are Problematic and Complex}

The idea conveyed in the Tunisian common sense, is that "disability" is a divine curse or even a kind of family punishment. Biases favored the patterns of exclusion of the person with a disability. Some virtual identity (Goffman, 1975: p. 12) monopolizes these people a form of etiquette and social tagging. They undergo daily hostility of their social environment. Indeed, this community is in much more poverty and insecurity than the rest of the population. The disabled Tunisian from a disadvantaged family can hardly afford the care of his health. Disability increases its poverty, prompting some families minted handicap to make an income. According to Goffman (1975) be stigmatized causes, the consequences of victimization because it is often exposed to charlatans. After, the motivation came to erase this stigma. The stigma is trying indirectly to improve social condition and to better control its operating field. Disability becomes a capital survival point. The life of the disabled community is often doomed to failure. Yet some manage their social life such as the case of some of disabled Tunisian.

Since Seoul in 1988 the Tunisian disabled offered Tunisia the honors. Despite the limited financial, technical and material affordability to the Tunisian athletes for the Paralympic Games and World Championships, the disabled Tunisian athletes have built a relevant track record and gave an example to follow by 
reversing all standards. They advertise a paradox with our Tunisian elites "healthy" when world exploits remain scarce and discontinuous.

This study exploits the sports practices of elite disabled athlete in the current Tunisian society. It helps contribute better understanding of the issue by expanding knowledge on representations of elite athlete disabled sports in general and especially their sporting careers.

What could explain these achievements and performance? They hide in their routes, a different paradigm in the process of technical rationality and to better understand the logic of these exceptional athletes and their unusual success?

The article offers a sociological analysis of the career of two handicap champions. Qualified athletes' exceptional which they are far away from us and very close, because sometimes it will take a spark to change the course of the life. (Hubert, 2016: p. 4). This analysis offers a different explanation of the preparation of elite athletes. An analysis focuses on the explanation of environment that accompanies the disabied athlete, on their constructive and destructive performances and on their individual logic and form of resistance to their disability. It is in the spirit of understanding how disabled sports champions in their social environments, their performances and in the tools that contributed to the progress and success in their development. The idea is to identify other influential idols in the career of a Tunisian disabled sports athlete in the high level competition. How our athletes defied their disabilities to succeed in their sports career and the demands of life? Is it a coincidence?

Even when one recognizes that the sporting career is a particularly significant phenomenon in the experience of an athlete, the various studies conducted to date, show widely varied reactions and psychological difficulties.

The next section presents the procedures surrounding the realization of this research. The choice of the methodological framework is described as well as the recruitment procedures of participants and their characteristics. Finally, the last part explains the method used to collect and process data.

\section{Methodology}

We opted deep down the handicap for its visibility to common sense. We chose two champions. The choice is based on their track record and Paralympic medals.

\section{Interviewees: Charts and Vital}

"W" Is an unmarried man, born in 1985 of a medium precarious family, active in the middle-distance events in the category "T34". Holder 5 records handicap sports world establishing 16 years of sports career. He was caught meningitis at the age of 2 years. He started his sports career at the age of 16 years.

" $\mathrm{H}$ " is single woman, born in 1977 of an insecurity acute, active in javelin world champion in the F54 category in 2015 and silver medal in London 2017. Establishing 14 years of sports career. She suffers from a spinal cord injury in 
1997 , late disability at the age of 19 years old. She began her career at the age of 26 years.

The choice of the qualitative method of analyzing life stories allowed us to identify the content of the timeline and to understand the meaning handicap athlete. It provides information of the social and sporting reality of athletes with disabilities, their situations as they were experienced and perceived. It helps to understand from within the guidelines of our interviewees.

The choice of the qualitative method of analyzing life stories allowed us to identify the content of routes and understand the sense what gives the athlete of his wheelchair. It provides an account of the social and sporting reality of athlete's handicap situations as they were experienced and perceived. It helps to understand from within the guidelines of our interviewees.

The uses non-directive interview (Blanchet, 1985) research as a data collection device allowed the elites to freely express their ways of thinking, their forms of resistance, their positions and their representations. according to Abric (1994: p. $60)$ to identify social representations both methods are the most relevant: Some, which we consider interrogative methods, is to collect an expression of individuals on the subject of the representation studied. This expression can be valid or figurative. The other we call associative consist also on a verbal expression encourage to make more spontaneous, less controlled, and therefore more authentic hypothesis.

In order to determine the milestones and the sparks that led to the subsequent consecration to be an exception to Paralympic sports, maintenance is guided by questions interested the degrees of contribution of the athlete and his significant inner as well as the sports institutions. Many situations are data collected among Interviewees: the field of study, place of residence (old and new), age, family status and their parents, school level and the job held.

The maintenance guidelines are distributed on three themes:

- Civil status:

The family structure, socio-sporting context (socio-professional status and family before and at the beginning of years of initiation.

- Social and sports state:

The choices undertaken, renewal and readjustment during the journey.

The meetings and their implications.

Effective logical course for success: rational and/or less rational.

- Social state:

The planned conversion.

Most of the thoughts state that to achieve the desired purpose and pass the necessary input from the instrumental rational and strategic system well established and developed, Tunisian handicap athlete showed other opinions more tentative and much less scientific rigged. An operative and effective thinking gives creativity; the power of intervention is the "creative imagination" (Dousset 1959: pp. 167-168). The imaginary exits the cops mutilated to get up and reach the imaginable whose excellence. 
It is thought in other ways help the success of our athletes that this article is true.

\section{Results}

This section describes the results of phenomenological data processing. These results are presented in two interviews exposing the unique experience of each participant. Then, a cross-sectional analysis of verbatim helps to highlights the most significant commonality of experience of the participants in relation to the research questions.

The four stories are the outcome of the analysis of data collected in semi-structured interviews, conducted, with two participants (one woman and one man). As noted above, these moments correspond to specific time. Verbatim extracts are also inserted in the stories. They differ in that they are quoted. For grammatical and syntactical reasons, sometimes verbatim segments are somewhat modified. Finally, a cross-analysis of the various stories will bring out the essence of the phenomena studied.

\subsection{The Pre-Career}

\subsubsection{The Social Conditions of the Interviewees}

The relationship between sport and social environment determines the social representations of the sporting career of our interviewees and strategic choice that they used to achieve their career. Analysis of life stories, taken as a social space, according Bourdieu, 1978, tells us about this close relationship. it tells us about the sports socialization of Tunisia with disabilities in terms of career achievement, the position of practice in the social space, especially in the sports area to deduce the construction of a specific social space in sporting activities for people with disabilities in Tunisia.

Involvement in a sports career can be expressed in this logic by an escape of the family context and especially environmental as expressed by " $\mathrm{H}$ " " $I$ was born in Sfax a family situation of very low scale, a father often unemployed and illiterate, a mother overwhelmed by fatigue, lack of means and extreme brothers and sisters lost. From a social environment without mercy. I saw myself die each day slowly. My involvement in sport took me out of my black hole."

The impact of parents in the education of the interviewees is crucial part in the success or failure of their athletic children. The roles of both parents in the education of their children seem to be lean. " $\mathrm{H}$ " education and schooling do not figure in the concerns of his father "He decided that girls should stay at home and only the boys enroll considering we were many. He tried to take care of me, but the lack of means made him far away from me" Walid is on the social context and the hostile gaze of his school that he pushed to leave school. He expresses "I decided to stop school against the advice of my parents, especially my mother. I could not stand the opinion of people and their segregation.” 


\subsubsection{The Social Context}

The education and schooling have been erased by the extent of the disability damage. Mothers have spent the majority of their time with their child. They are more concerned with their rehabilitation and their autonomations: "My mother took more care of me. My mother has always lived with my disability. She was the one who encouraged me to join the center." States " $\mathrm{H}$ ". "My mother was always with me. She encouraged me and cared for me. She was afraid so she took me to the center of vocational rehabilitation of disabled drivers and accidents of life to integrate into society." Expresses "W"

The very idea of sport was not an option, and no one valued the competitive investment given the lack of resources and the lack of information on this practice:

"No one in the Family had imagined that sport could save me." Expresses "H"

\subsubsection{Poverty and Disability}

If " $\mathrm{H}$ ", living in a popular uncertain environment, makes us think she did not have the conditions necessary to lead a decent life. To achieve this convenience, she spends the days in the only rehabilitation center for the physically handicapped. This center provides their daily diet, their education and training. It is a place of assistance to the poorest families and a method of protection against delinquency children: "We lived in a popular neighborhood, and it was not very safe." Develops " $H$ ". This also the case of "W" who spends his days in the center but he did not live there. The center was in his governorate. " $H$ " did not have a luxury lifestyle. This shows that "W" lived in a less fragile situation "H" "So I live in Manouba and the center was not far. I did not have much choice, no way to escape my horrible destiny."

The rehabilitation center for physically disabled and accidents life is the most recognized and where the majority of disabilities enroll for insertion and future autonomy as stated " $\mathrm{H}$ " "The only we knew. The social worker pointed me to this center and my mother accompanied me. I hated it, it made me even feel my disability and my weakness, but I had no choice. I did not want to go home and our poverty, [...], which is important for me in order to make a living."

Some poor families as the case of the family of " $\mathrm{H} \& \mathrm{~W}$ " enroll their children in special centers and receive aid, not monetary but rather humanistic ensuring, during the accident of their child, a life rebalancing while providing a healthy lifestyle. This is a direct family assistance from public aid for better social integration. An erroneous insertion as formulated "W": "I learned the jeweler's craft, but I was not convinced. I had to learn a skill in order to integrate myself in the society. It is a false integration because in Tunisia we do not integrate. Being disabled in Tunisia it's horrible. It is a cruel disability society. We already expelled before you even starting." Other factors, such as contact with practice, the beginning of the engagement practice and the increase 
of his friend's circle outside the sport contribute to the positive effect of the self-acceptation and a beautiful sports career.

\subsubsection{The Sports Career}

1) The meeting with the sport, less rational logic:

Contact with the practice:

The content analysis of the life stories of "W \& $\mathrm{H}$ " affirms the existence and coexistence of other less rational logic in the development of a disabled athlete career and explaining their success and resilience. The deployment of the strategy of a less rational action that characterizes the disabled athlete facing the trials of life. The quarry is a valuable tool resilience. It allows the reinvestment of disability.

The beginning of our interviewees was not directed to career discussion, the circumstances in which both athletes began practice are by chance. The choice of crafting themselves as an explanatory paradigm of the course is supported by several statements that confirm the progress of a journey outside the direct interference with institutional development and redevelopment of their journey. Indeed, both have encountered the practice in vocational rehabilitation center for physically disabled and accidents of life in Manouba: "I met the practice by chance. I lived in a vocational training center for the disabled and a coach approached me." It's the coach $X$ that I detected. He referred me to the discipline of racing wheelchair. He saw me at the center spirited play with my chair. I was very adapted with it. So he offered me to join the Athletics wheelchair, I was curious express successively " $\mathrm{H} \& \mathrm{~W}$ ".

The two champions have not therefore followed or planned specific steps in order to be champion. In the early days, their journey is characterized by random action and subsequently a family intervention specifically their mothers as is the case of " $\mathrm{H}$ " "My mother told everyone that her daughter is strong. And especially during my career, she often repeated this sentence to me because I was fighting. She wanted to prove I was better than everyone else."

The role of the mother of " $H$ " and " $W$ " seems more significant one at the beginning of the "formation" "When she understood that sport can save me, she encouraged me and inspired me to continue." Expresses " $H$ "

For the mother of " $\mathrm{H}$ ", it is an opportunity to prove to her family and her environment that her daughter did not suffer punishment or a curse but a blessing. Indeed, in some circles, is still considered disability as a curse or divine punishment for the person or his parents. A disabled child in a family is necessarily a bad family and that divine justice punished them.

The life of " $\mathrm{H}$ " changed the first time when her father decided to stop her schooling, the second time when she fell ill and became disabled at the age of 19 years and the third time when she met sport. Sport is, " $\mathrm{H}$ ", the beginning of an adventure into the unknown as it develops: "The sport was for me an opening to a new world especially since I started my career at 26. I had absolutely nothing to lose. $I$ wanted at all costs to change my life and devote myself to 
another". As for "W", he started at 16. From the first contact, he gave a goal to succeed by any means: "I started my career when I was 16 . I was hesitant at first. He told me to try it first and judge later. I tried, and I've taken the bait." Develops "W".

The commitment in practice and the start of a career-yourself:

Guardianship gives the Tunisian Federation of Sports Disability modest financial and logistical resources. The athlete has the support of guardianship in the elite athlete contract program and a leader status in case of winning several medals. Athletes disabled sports glean a lot of medals compared to bodied athletes but are often forgotten and do not enjoy the same favors and corporate subsidies. Indeed, compared to other aids, the market using wheelchair remains insufficient for their needs. At these words "W" states: "I suffered in my travels, I rode the subways and I was bothering everyone. I could see it in their eyes. I did not have money. I used moderately what I had opportunity and money wise."

As for " $H$ " "I had some money. I moved around by subway, I was preparing to eat alone, I trained without any absence, if I could do all alone with my means of edges."

In 2012, "W" was medalist after 10 years of hard work and continuous uncertainty. He was taken to consolidate all its efforts physical and social life in a reduced time to achieve success. It states:

"Early in my career, I had absolutely nothing. I started a new practice, a new mindset and a more complicated life but with a future glow. I struggled alone to get to the workouts. After 5 years of hard work, I had my first monthly $50 \mathrm{~d}$ scholarship. A ridiculous payment for a great future. For workouts, you need to train with your mouth shut because he or she who has not won a world medal has no rights. I persisted, I got involved and I have everything fixed around my success with all the aspects of social life." In the same year of its commitment in 2004, " $\mathrm{H}$ " still living an intense insecurity stands in fourth place in the Netherlands and in 2007 she won her first medal. She found a means of upward mobility, a late but effective way. In its beginnings, in her years of investment, she found the support of her coach. During this year, her only aim in engaging in this practice, is purely monetary, " $\mathrm{H}$ " openly expressed her profit: "My first coach told me to think of Tunisia to the top of the poster, to hoist the Tunisian flag and the national anthem and I answered any elite athlete can do. The flag does not fill my empty stomach. [to laugh]. I want money. I can die for money. I want a medal for having money and support myself, [...] since my contact with the sport I reorganized my life. [...]. I cannot perceive with a ridiculous amount of $50 \mathrm{~d}$." Moreover, " $\mathrm{H}$ " as evidenced by: "Nothing was set in advance. Once I seized the opportunity I left everything behind me and I built my way alone. I was hungry for passion and rage to rebuild my life. All means are so good for my purposes". Life the frame " $\mathrm{H}$ " was made expectations, uncertain bet, wise or crazy, characterizes the entire career and is clearly manifested by restorative 
work and builder. So this is how "W \& H" were not expected to achieve such performance. "W" refers to the year of the beginning of his dream: "I wanted my medal, so I triggered and amplified my actions of all kinds. Besides, I plan to participate in the Olympic Games 2020 and World 2022."

" $\mathrm{H}$ ", with passion and with a third person, his coach: "My coach, younger than me by two years, believed in me and helped me to overcome my obstacles and my strength.”

It is identified as "A brother, father and even an angel."

The refrains repeated several times as "my hope" and "my passion" reflect the supremacy of passion over reason and that reason is governed by passion: " $M Y$ passion for my practice has developed during the evolution of my actions and the years. This is my break, my source of life."

Once the impossible has become possible, the institutional framework has responded that the actor creates. A reaction seems to accession and a support which has multiplied and amplified, and where guardianship has guaranteed certain expectations of the actor. As the case of "W": "When I won the first time, guardianship began to believe in me. I had my own wheelchair adapted to my size."

So the design of the real is the result of action. In fact, this result is driving passion made possible by a haphazard order in which uncertainty and there are chao figure. Once in the medal production system, disability is no longer visible. The athlete is now considered a healthy athlete or rather a coin machine. As the saying "W": "He told me you're too late! If you do not bring a medal as soon as possible, you will not be on the list next time."

Passion is automatically carved with anxiety the result. The athlete becomes disturbed and emotions mix and become chaotic, but the only clear idea is to succeed. It is in the social disorder that the Tunisian athlete wheelchair finds its order. The disorder becomes organizer as " $\mathrm{H}$ " affirmed: "For years, I was in total mess, but I reached to my goals at the end."

It also says: "I do not know how I could overcome all my problems from my disability to date and surpass all the mess I was experiencing. But thing is sure I worked hard, I have also a lot of determination and I developed a force to overcome anything. The proof, I $m$ 40, I'm still performing." states "H"

From this point of view, the disorder becomes organizer and rough and precarious order because, constantly challenged by both elites always willing to negotiate their life course.

2) New approach to disability:

Behind the adoption and introduction into the world of disabled sports practice, disability of "W \& H" during the course of the career, passes also through phases. They go through a lazy label to a valiant label.

From cursed disability to exploited disability to revered disability:

$\diamond$ The cursed disability

This is the first report with the late handicap: "I hated my disability, it de- 
stroyed me. I did not have neither present or future. I saw only death before me especially with the animosity of my environment." Develops " $\mathrm{H}$ ". A disability that leaves both very distant social and very close since she now wears a disability label. It is important to distinguish late handicap native. Late is harder to accept and manage:

"I was 2 years old when I had my debilitating fever. It was in college that I started to curse my disability. I especially hated all school due to the weird look of teachers, friends, parents. I did not accepted My disability since I met the gaze of others." Enlighten "W".

3) The exploited handicap:

In their thoughts standardization and assimilation, research of the same sport is laid for our athletes, as a normalizing activity of the disabled, that is to say as a mediation towards integration and their civic participation. Once ( $W \& \mathrm{H}$ ) have seen their sport socializes potential and future promoter, the disability was the cursed the exploited: "My disability makes me sick and distressed. When I realized that my disability can become my source of life, I used it and tried to profit from it" And says " $H$ ".

As for "W", he states: "I used my disability to my interest. The important thing is to reach my desired result" "W \& $\mathrm{H}$ " saw in their disability a capital. They went through emotions, thoughts and negative prejudiced of their disability to positive construction. The mechanical normalizing is running. Indeed, sports preserve the prevailing social values, sportsmanship becomes a tool for education and integration. The moment of debilitating disease exploit and transform into opportunities; the hope to succeed allows the athlete to surpass his or her disability in order to overcome the adversity. This is expressed in " $\mathrm{H}$ ":

"I imagined my success and my victory. I just wanted to win the competition. I imagined all the possible scenarios: the good and the bad. I convinced myself, I pushed myself not to flinch, I saw my life back if I lost. And I was afraid to live again my old life. I bet everything on the day of my competition. I fully exploited my body and disability. I decided to win. I thought: I have to change my life and have a normal life is now or never." When a "W", the feat of his disability and says:

"How do you explain that? It was grueling and very hard. I had to sum up and exploit 10 years of intensive work with a disabled body all my life of hostilities in 12 seconds. I banned the fault. I was scared. Yes. My future depended on it. I had to defend another image that people gave to my appearance. I preferred to have the image of a disabled athlete."

\subsubsection{The Revered Handicap}

Our athletes were treated to the social visibility of their sporting excellence as the case of " $\mathrm{W}$ " and " $\mathrm{H}$ " by stating: "Today, everyone recognizes me and insisted on meeting me and interview me when before I passed unnoticed. My Medals allowed me to assert themselves and become a local and global reference."; "My medals are my strength and my personality visibility." 
After the medal won, an awareness of their capabilities, strengths and weaknesses takes shape. A social reconstruction emerges. Reconciliation with their disability and social settle. The cursed disability becomes instantly revered: "I love my disability ... My disability is a blessing! I thank God. If I were healthy, I would not have had all my comforts of today. My handicap allowed me to succeed. All that is beautiful in my life is related to my disability." States " $\mathrm{H}$ ".

As for "W": "Today I cannot imagine my life without my disability. Now I have my world and my marks. With my disability I could live."

The wheelchair has changed, too, representation. From the first medal and real compensation, the wheelchair takes other dimensions and meanings: " $M Y$ sport is my freedom chair. It's amazing how I hated it before and now I love more than anything. She's my friend, my wife, my time, my freedom. Everything I have is because of her." Formula "W" My chair is a part of my body, it is inseparable, and I learned to love it. She is my profile and my independence. "Reveals Dictates" H.

\subsubsection{The Perception of End of Career}

In this perspective and as confirmed by "W": "Sport is a career among others in the life of a healthy individual when we say to the sports community to handicaps". "W" states to subject: "I already have a plan for my conversion. After my participation in 2022, I plan to be coach. I hope in my turn to identify future champions. And especially help to improve the situation of Tunisian wheelchair athlete". "These words are also confirmed by ' $H$ " I am considering having my first facilitator diploma. After my career, I'll buy a house, in fact I am trying to look for it, and create a small restoration project. I love food. Thus " $\mathrm{H}$ " states: "I do not want to fall into oblivion and especially not in need. So I prepare myself ... I want to continue my career and my image while providing me a good income."

\section{Discussion}

The discussion shows link the results of the study with those of studies being concerned about it. The study attempts to answer two research questions, 1 ) how disabled athletes they experience their potential sporting careers and 2) how to prepare themselves for it.

The pre-career

The social origins of our two interviewees are characterized by high uncertainty about the possibility of finding in the near future a better situation. They live in the absence of environmental safety conditions.

Due to the socio-professional family, the Tunisian living with disabilities, from an early age, learning to build its identity (Dubar, 1991: pp. 33-39) and gradually adapt to the executives of socialization (Lahir, 1995: p. 19). Starting from its place of establishment while going through his first agent of socialization is the family (De Singly, 1995: pp. 11-32). Both interviewed, "W and H" are 
both from disadvantaged society.

Popular social origins of two interviewees are usually compounded by the weakness of family cultural capital. Social background, employment status and the level of parental education " $\mathrm{W}$ and $\mathrm{H}$ " can be considered logically as a process of stimulation and orientation sports career. Indeed, in order to break away from the social and cultural domination, both athletes are making individual strategies to be dislodged from that environment.

We are in front of two people who live mostly double discrimination in almost all areas of social life, those of person accessibility disabilities and vocational training, etc.; and those poor person in terms of insecurity, access complexity, etc. We started from the idea that poverty and insecurity are two related concepts, "the current notion of poverty is still strongly colored by the original meaning of poverty." However, according Offredi, these two notions precipitate transformations and different social effects "In the space of the poor, [...], can match an identity, [...], collective and individual stigma universe of symbols. A space of precarious, mobile and discontinuous seems to fit the paradox of an identity built on the "provisional" [...] the precarious alone, different, eradicated in its relation to space." (Offredi, 1988: pp. 21-32). What arouses more difficult to overcome for "W \& H". The family is generally seen as a means of "protection against poor living conditions, isolation, and alienation." (Pitrou 1978: p. 219) which is not the case of "W \& H". They live in a situation of insecurity and extreme poverty.

According Pitrou (1980: p. 12) "The first characteristic of precarious is indeed that it has no control over the future. Not only has no control over the events on which it depends vitally (employment, working conditions, revenues, cost of living), but in addition, it does not have effective means individually or collectively to overcome the difficulties that arise". It has no financial reserves. He or she are perpetually threatened to see their status deteriorate, living conditions become more difficult, and even life itself be broken by illness, accident or premature aging. "Knowing that" poverty characterizes the situation individuals, groups, destitute deemed essential resources and are in a precarious [...].

It is difficult to define poverty in absolute terms, it is a concept generally considered relative and that refers to a variable standard according to the times and societies: being poor does not mean the same thing in the US and India; in France in the nineteenth and twentieth centuries (Echandemaison, 1989: p. 2018). In Tunisia, poverty is defined in terms of money and poor (Nasraoui, 1996: p. 23) are defined as individuals or families' material resources, cultural and social are very minimal. The risk of ending up in less privileged backgrounds accentuates Disabilities. "(Poizat, 2009: p. 31), which pushes people with disabilities" to isolation, lack of hygiene, lack of social life, insecurity and begging. The material factors seem to be the determinants (Godin, 2010: p. 61), this link between poverty and disability and increasing distress and fear.

The job sector or job insecurity of parents and future employment of people with disabilities in situations unconsciously develops in an interviewe some an- 
xiety and uncertainty about their future. "The social phenomenon considered negative and central." (Barber, 2005: p. 46) and "social paradigm." (Pogam, 2000: pp. 155-159), called "precariousness" precarity of parental employment, precariousness of the family and the uncertainty of the environment shows that the wheelchair athlete from a low socio-economic organization or unsuitable, in addition to his disability, clashed from a young age to a form of social exclusion. "The vulnerability, inability of the family to cope with the duties assigned by society, economic constraints and disability with the feeling engendered exclusion are often emerge special cases" (Pitrou, 1978: p. 133).

\subsection{The Sports Career}

Sport is used by " $\mathrm{H}$ " as a tool to "trigger." (Marcellini et al., 2003: pp. 59-72), which illustrates the one hand, its ability to take the risk of engaging late in sport, its ability to act on its decision and to assume the consequences of his actions and even to anticipate his actions. And secondly, it demonstrates its ability to promote physical and mental environment. Disability therefore and indeed a capital.

Both athletes have practiced athletics in the same year of their integration center. The professor from the center, this time, was to recruit people with motor disabilities. Besides the recruitment of "W \& H" was done between 2003 and 2004. It should be noted that athletics is the only discipline in which Tunisia has competed and won medals for his participation in the Paralympic Games. From 1988 until 2004, athletes have won 14 gold medals, 13 silvers and 6 bronzes. The curiosity and the need to change the living environment have pushed the two athletes to engage in this field and to invest despite the difficulties and resistance from social daily.

\subsection{Building a Career}

The first good results of our interviewees revealed the coming of a champion and led the review of the uncertainty. It is through their commitment to fight poverty, disability and stigma they decide one day become top athletes and super elite. However, this statement illustrates some rational conceptions in the identification of promising topics process. Indeed, the two champions have not used the predispositions required for success as the rationality of sports courses at high level demanded specific standards, scientific talent identification processes well studied, etc. States " $H$ " began at age 26 and "W" so at 16 they started their careers without passing through "the references to success and progress. Of (Cote and Hay, 2002, p.17). They jumped the years of sampling (6 - 13 years) and specification (13 - 15 years) and were recruited directly in the years of the investment, 16 and over, and then they are persisted in the years of support. This diversion process is one of the aspects that "rationality usually avoids because it is considered an imperfection, a waste it is important to do the cleaning" ( $\mathrm{Ar}$ doino, 1990: p. 22). Hence the interest of do it yourself technique.

Both athletes have combined several years of training in a record time. Their 
day is to just put all the factors in their favor even more unpleasant. Neither subway nor tiredness, or lack of money can keep them away from their sports career goal. They tinkered career by merging the first two phases of its development by relying more on manufactured and cobbled factors according to circumstances and the need of the moment. Their success is based more on the three success factors developed by Burand \& Salmela (1994: p. 34) that "the human environment, personal factors and investment of sports." In this phase, the interviewees show their ability to adjust their behavior to a fully open environment to individual crafts. No action plan has been established but a reconstruction process of choice and route was established as opportunities to seize or create. The analyzes conducted in the near our discussions related to questions about the objective decided at the start of the sporting commitment, or if it was established as and the career development, according successes clear; inspired the social production of our interviewees do not follow a rational order reducible to cause and effect but it gives room for individual variation and subjectivity. Indeed, "This is the passion, which refers to the action, which it is the necessary complement" (Javeau, 2004: p. 77). Our elites are driven not only by the desire to change their lives unnecessarily handicap but also their passion developed during their sporting career. A passion generated as the years pass and built by trial and error. It puts the weight of the objective explanation of their behavior Duvignaud (1990: p. 208) calls "conducted without purpose." According Duvignaud (2000: pp. 45-61) first, "it agrees then be explained with oneself and others." The company that we are given is a different reality where desires that more needs-based communities liberated from the past, profitability and inequality. Passion is considered transgressive behaviors feared by the social. The passionate, in fact, is working to "confront the impossible desire items that the idea does not yet exist. And that, outside the norms, institutions, rules." (P. 209). Passion is "an aspiration towards the non-given, the not-yet-lived, the realm of the possible" (p. 210).

Our interviewees are engaged in a chaotic movement (Nietzsche, 1967) their career is filled with trial and error, balance, imbalance and rebalances, organization and disorganization and subject to complex systems composed of different elements and reciprocal influences. Timing is everything and disturbances around them, followed the implications of certainty of loss, maintenance, sporting careers, conflict and discord. For this lack of certainty, athletes show an inability to explain the progress of their success and believe that this uncertainty has been present for family socialization, reinforced by the function of maintaining sporting and social guardianship up to acquire a professional status.

In conclusion, "Social is a place of permanent disorder, framed in its margins by thin layers of order" (Javeau, 2004: p. 80). "The order and disorder are so inherent to the social. They are "inseparable whatever the path that leads from one to the other" (Balandier, 1988: p. 43). So "Structuring is not a smooth process, and no more a unique process. It is the expression of constant trial and error which social actors indulge to write a story they are rarely able to predict, or 
even to read afterwards" (Javeau, 2004: p. 69). The social order appears as Javeau (2004: p. 225) as the result of a "structuring groping, the product of an incessant work of trial and error, led by actors with a stock incomplete knowledge, lack information about the intentions of their partners [...] and unable to correctly measure and predict the consequences of their acts."

The physical and social disabilities, insecurity, social exclusion and the provision of sportsmanship are the primary determinants of engagement in sports course of "W \& H". The "malaise in culture" Tunisia (Mead, 1984: p. 2), pain and discomfort experienced by interviewees also promoted their sporting distinction. An exceptional success that first results from a competition with oneself and competition with social as specified Yonnet (2004: p. 72) "In competition with yourself about the challenge embark sports during these activities." The obsession with performance and competition have penetrated all the activities of our contemporary society, including the sports community of Tunisian wheelchair, causing engagement and profit for future social development. An exceptional success that also results of deconstruction and reconstruction logic, opinions, beliefs, ideas, etc.

\section{General Conclusion}

This study aimed to understand the experience of a sporting career among disabled athletes. A comprehensive approach and constructive experience of participants were discussed. It was to see which way these athletes give to this transition in their sporting career. The study responded to two research questions: 1) how disabled athletes experienced their potential sporting careers and 2) how to prepare themselves for it.

The results have identified several phenomena connected to the experimentation of the possible sports career: 1) negotiation between the start of the sporting career and hope to be rescued, 2) the transformation process of "athletic Me", 3) the termination of the group experience and 4) the confidence to face any test at the end of a sporting career.

Both participants "W \& H" of this study are, in part, the product of training policy elites by established structures which ensure in general, the destinies of sport and athletes. They are mostly "the product of institute capabilities" (Sallabery, 2003: p. 79) and creating the subject themselves, those of their individual situation with disabilities and social and representation of their stigma, marked with the seal Do It Yourself.

The uncertainty of the socio-professional environment of the family, the lack of funding, and lack of education and protection, etc. form some motivation that encourages outdoing and out of the "victimization phase" (Goffman, 1975: p. 149). The minimum subsistence deprivation leads to a disabled person in a revolt behavior and encourages the response. The response is through multiple paths. The need to assert themselves, to erase this "particular disagreement between the virtual and real social identities" (Goffman, 1975: p. 12), and restore 
the representation related to stereotypes of a person with disabilities in Tunisia,

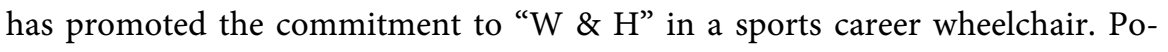
verty, disability and destruction of uncertainty triggered opportunities to reach what may be the first plan or social advancement ploy to "W \& H" and what are the side benefits of their disability and the beginning of a sporting career. Indeed, both have survived the social and sporting complex. The complexity defined by disorder, subjects to a "permanent displacement in the history of thought and human society" (Morin, 1982: p. 196). Moreover, "the order is inseparable from the disorder" (Morin, 1982: p. 193), he must leave to chance and uncertainty; the disorder can indeed be creative (Prigogine, 1995). The complexity is a messy object, object of a "permanent displacement in the history of thought and human society" (Morin, 1982: p. 196), it draws its "energy in its environment" (Morin, 1982: p. 171). This concept of complexity mingles with DIY and thereby occupies a central place in the Tunisian sports field in general and in particular wheelchair.

Despite their disabilities and their dependencies with regard to the Tunisian institution, "W \& H" retain a large degree of autonomy and power of individual actions. They established a process characterized by "Mobilization of the imagination [...] sole source of radical creation" (Ardoino, 1980: p. 146). Indeed, those are individual cases of the sporting success of athletics for the disabled. Two major inter-related events are marked in the education system of our elite athletics disabled sports:

1) The link between athletes and the structure where sports tinker in building their career into perspective their options pleading for arranging the power "structures by internalizing the externality" (Bourdieu, 1980: p. 92). Determinism gives way to a largely unknown social, at the discretion of the disabled sports athlete engaged in action.

2) The link between the rational and the irrational; athletes on the rational in their elite career training plans. Rationality is limited because to build the desired reality, incompatible modes operate at the expense of formal rationality. It has been attempted to show that it is among DIYers athletes manifest the creativity of humans and their power of invention.

The field of disability sport is crossed, since its creation, by legal problems. By problems on recovery plans, deployment strategies, and all the rationalizations implemented. These devices remain fruitless because the sport system fails to limit its own messy moments thus promoting a dynamic of change. Rational operation remains problematic. Our analysis provides a perspective of the current system.

DIY (Javeau, 2004), passion (Duvignaud, 1990), stigma (Goffman, 1975), the social representation (Abric, 1994) assembled with rational subjectivity restore an important place in the path of a wheelchair athlete and decision to consider the objectivity of a sporting career. It is "the royal road to objectivity" (Devereux, 1980: p. 227). 


\section{Conflicts of Interest}

The authors declare no conflicts of interest regarding the publication of this paper.

\section{References}

Abric, J.-C. (1994). Méthodologie de recueil des représentations sociales. In J.-C. Abric (Ed.), Pratique sociales et représentations (sous la direction) (pp. 59-82). Paris: PUF.

Abric, J.-C. (1994). Pratiques sociale et représentations. Paris: PUF.

Ardoino, J. (1980). Education et relation. Introduction à une analyse plurielle des situations éducatives. Paris: Gauthier-Villars.

Ardoino, J. (1990). Les postures (ou impostures) respectives du chercheur, de l'expert et $\mathrm{du}$ consultant. In Les nouvelles formes de la recherche en éducation au regard d'une Europe en devenir, Actes du colloque international francophone de I'A. F. I. R. S. E. (Alençon) (pp. 22-34). Paris: Matrice-ANDSHA.

Balandier, G. (1988). Le désordre: Eloge du mouvement. Paris: Fayard.

Blanchet, A. (1985). L'entretien dans les sciences sociales. Paris: Dumond.

Bourdieu, P. (1978). Comment peut-on être sportif? Questions de sociologie (p. 189). Paris: Minuit.

Bourdieu, P. (1980). Le sens pratique. Paris: Edition de Minuit.

De Singly, F. (1995). Le couple, le soi et la famille. Paris: Armand Colin.

Devereux, G. (1980). De l'angoisse à la méthode dans les sciences du comportement, Flammarion.

Dousset, R., \& Corbin, H. (1959). L’Imagination créatrice dans le soufisme d'Ibn' Arabî. Archives de sociologie des religions, 7, 167-168.

Dubar, C. (1991). La socialisation, construction des identités sociales et professionnelles. Paris: L'Harmattan.

Duvignaud, J. (1990). La genèse des passions dans la vie sociale. Paris: PUF.

Duvignaud, J. (2000). La scène, le monde, sans relâche. Revue Internationale de L'imaginaire, 12, 45-61.

Echandemaison, C.-D. (1989). Dictionnaire d'économie et des sciences sociales (p. 218). Paris: Nathan.

Godin, P. (2010). En pays Kanak, des malheurs et des hommes. Gardou, Ch.

Goffman, E. (1975). Stigmate: Les usages sociaux des handicaps. Les éditions de minuit.

Hubert Ripoll (2016). https://informations.handicap.fr/a-resilience-sport-ripoll-9102.php

Javeau, C. (2004). Le bricolage du social. Un traité de sociologie. Paris: PUF.

Lahir, B. (1995). Tableaux de famille. Heurs et malheurs scolaires en milieux populaires. Gallimard.

Marcellini, A., De Leseleuc, E., \& Gleyse, J. (2003). L'intégration sociale par le sport des personnes handicapées. Revue Internationale de Psychosociologie, 20, 59-72. https://doi.org/10.3917/rips.020.0059

Mead, M. (1984). Société, traditions et technologie, les publications de l'UNESCO. In M. Douss (Ed.), La place du corps dans le contexte culturel tunisien actuel entre le traditionnel et le moderne (p. 2). Thèse de doctorat en sociologie, Paris: Université de Paris.

Morin, E. (1982). Science avec conscience. Paris: Fayard. 
Nasraoui, M. (1996). La représentation de la pauvreté dans la société tunisienne. Paris: L'Harmattan.

Nietzsche, F. (1967). La volonté de puissance. Tome 1, Paris: Gallimard.

Offredi, C. (1988). La précarité des années quatre-vingt ou un phénomène social en gestation dans la société. Revue Internationale D'action Communautaire, Printemps, 19, 21-32. https://doi.org/10.7202/1034237ar

Pitrou, A. (1978). Vivre sans famille? Les solidarités familiales dans le monde d'aujourd'hui (p. 219). Toulouse: Privat.

Pitrou, A. (1978). Vivre sans famille? Les solidarités familiales dans le monde d'aujourd'hui (p. 133). Toulouse: Privat.

Pitrou, A. (1980). Qui est pauvre (p. 12)?Économie et humanisme, juillet-aout.

Poizat, D. (2009). Le handicap dans le monde. Érès. https://doi.org/10.3917/eres.poiza.2009.01

Prigogine, I. (1995). Le désordre créateur. In Tribune libre d'llya Prygogine, Serveur IRCAM. Paris: Centre Georges Pompidou.

Sallabery, J.-C. (2003). Théorie de l'institution et articulation individuel-collectif. In J. Ardoino (Ed.), Actualité de la théorie de l'institution: Hommage à René Lourau, L'Harmattan. Paris: L'Harmattan.

Yonnet, P. (2004). Huit leçons sur le sport (p. 72). Paris: Gallimard. 